\title{
Brief Study of Social Culture Color Embodied in The Hours
}

\section{-Analysis of the Patriarchism in The Hours}

\author{
Rongqiong Guo \\ Xi'an Peihua University, Xi'an, Shanxi, China, 710100 \\ Email:263168489@qq.com
}

\begin{abstract}
Michal Cunningham is one of the most brilliant contemporary American writers. The Hours, published in 1998, has gained a resounding success and awarded Pulitzer Prize and PEN/Faulkner Award. Patriarchy is one of the key terms in feminist literary criticism. Feminists consider that it is a social system in which men are the principal authority figures. This paper aims at pointing out Virginia, Laura and Clarissa these three females in The Hours fight against their tragedy fate under the patriarchy society. By analyzing the hard course of their fighting and pursuing, this paper designs to explore the root of female's tragedy-ineradicable patriarchy. Thus, the coexistence of revolting and compromising make them lose image during their way of resistance and pursuit. Therefore, this paper has the positive meaning for the feminist movement and female liberation, which offers a new possibility that women's alliance overthrow the patriarchy downrightly, arises the reflection of female issues and continues fighting for female's real liberation.
\end{abstract}

Keywords: Patriarchy; Lost Image; Feminist Criticism

\section{Introduction}

Michael Cunningham is one of the most famous and popular American writers nowadays, he won the Pulitzer Prize for Fiction and the PEN/Faulkner Award because of his best known novel The Hours. The Hours established Cunningham as a major force in American writing. This novel is essentially talking about women. Women from different periods, of different ages, and oddly the same in various aspects. It is known to us all, in the patriarchy society, men are the absolutely dominators in every social aspects. Since the emergence of the feminism, feminists have done their best to lead all women to fight against the male-dominators. Even though they have got great success, the root of the patriarchy hasn't been removed. Females still suffer in the male-dominated society. This paper mainly focuses on analyzing three females' lost images in The Hours by their various ways of revolting the patriarchy. The first one is the Virginia who fights against the confinement of her husband and her role of wife by writing and disobeying the arrangements. The second is the dazed Laura who is keen to read and finds a job when facing herself. The last one is Clarissa who bravely chooses to be a lesbian and refuses to depend on men in order to relief from the imprisonment.

\section{Analysis of the Patriarchy}

Patriarchy is one of the key terms in feminist literary criticism, Patriarchy refers to the role of males in the society in which men take the chief responsibility over the community welfare by and large. The word "patriarch" derived from two Greek words: "patira," and "archy" which means family and rule respectively. Patriarchy can be understood as male-dominated, male supreme over female and androcentric in the society. More precisely, it means the female subordination and female inferiority. Moreover, patriarchy has already shaped by both female and male, for which male are the rulers while female are the ruled. Overall, Patriarchy idea prevailing in all social areas and rejecting patriarchy is the key step to the liberation of the female.

\section{Analysis of the Patriarchy of The Hours through Three Main Characters}

There are three females in The Hours-Virginia as a pioneer of modern feminism, Laura as a dazed housewife and Clarissa as a rebel free woman. Despite the different ages they live in, they all 
share one common that is they are totally lost in the patriarchy society. In other words, they are suppressed and suffered in the male-dominated world to varying degrees. Their tragic fates reflect in two aspects - they all attempt to fight against but have to surrender. Thus the combination of the resistance and compromise renders their images as the "lost lambs". In this paper, three females' lost images will be analyzed by revolting of the patriarchy and pursuing the freedom respectively.

\subsection{Virginia against Confinement}

The analysis of this part mainly focuses on the Virginia's efforts to fight against confinement of her husband, doctor and the servants. Her husband Lenard who loves her wholeheartedly and brings her to a rather small town Richmond for her good by obeying doctor's suggestion. Unfortunately, it brings no benefit to Virginia's health but makes things worse. She is suffocated by the tedious problems from the servants, the boring and vacant life in Richmond and her husband's imprison. Richmond is the representative of the patriarchy. Being a well-educated and lettered female, she is sensitive to the discrimination of female. During the late 19th century and early 20th century, women were supposed to live in a rather closed life for they had no right to speak, to work and to write. Virginia lived exactly at that period. As the second sex and the other, Even though she has no chance to choose where she should live in and what she wanted to do in the patriarchy due to the economic situation and feminine ideology, she attempted to do something to fight and change.

First, Virginia fights against the patriarchy by writing. As a female writer who has strong feminist consciousness, Virginia is trapped under the small town where she nearly drove crazy. She is suffered from patriarchy deeply. Therefore, she has to find a way to relief herself and writing is the only way to get away from the pressure from the patriarchy. As we all known, female reading and writing were forbidden at her time. She is lucky enough to have the opportunity to get educated and read freely in her childhood. As time goes by, she ignores the social restraints and starts to write.

But unfortunately, her mental disorder and spontaneous headache make her stopping writing. When she has her headache, she always hears some voices. Even when she is insane and suffers a headache, there is the male voices makes her crazy and insufferable.

In a word, writing, her way of fighting against confinement is still under control of patriarchy. On the one hand, her internalization of the other makes her will never completely break with the male-dominated society. Her own weakness makes her destined tragedy. On the other hand, the strong effect of patriarchy is at everywhere even when she is mentally disorder. She tries to write to avoid the carnal world and expresses her dissatisfactions about female's injustice situation. Thus, due to her own weakness and the steadfast patriarchy, her way of fighting by writing cannot be counted as a through success.

\subsection{Laura Facing Herself}

Laura revolt against patriarchy when she facing herself. Being a well-educated woman after World War II, she suffers a lot from the patriarchy. When she is in high school, she is "the bookworm, the foreign-looking one with dark, close-set eyes and the Roman nose, who had never been sought after or cherished; who had always been left alone, to read." (Michael Cunningham, 1999: 40) Her husband Dan is the war hero who survives in the battle and proposes her. She couldn't deny a good-hearted, sweet-tempered, handsome and particularly brave man who just has come back from dead. Then her name is Laura Brown who has no idea whether she loves Dan Brown or not.

She is an incompetent wife even she tries to be a good one. First, she hasn't done the housework as other housewives who are supposed to taking care of her families in male-dominated world. As we all know, a good wife should get up early to prepare the breakfast for her families. But on the contrary, she wakes up late, lies on the bed and reads for a while. Her husband and son get up early and wait her to eat together. Second, she is unwilling to fulfill her husband's sexual needs. At Dan's birthday party, Dan expresses his satisfaction and happiness about his family and life without any notice of her inner struggle. When everything gets done, she enters the bedroom and hopes to read, but her husband is waiting for her to remove the robe and climb into bed with him and have sex with him. She feels so depressed and angry about his way. She doesn't want sex at all; all her wish is to read freely. Her refusal to have sex with Dan is kind of silent resistance of patriarchy. 
She fails to be a good mother. As a housewife, her another duty is to take care of her children. First of all, she is afraid of being alone with Richard who is also a representative of patriarchy. She feels like being monitored by him- "He seems, almost always, to be waiting to see what she will do next." ( Michael Cunningham, 1999: 47) Alone with him, she always cannot remember how a mother should act. He is so entirely, persuasively himself and he always want what he wants avidly. Then. She almost kills her daughter in her belly. Giving birth to a child is the obligation of female in patriarchy. She should be happy to have a child. Actually, she is not. When she feels so depressed in that beautiful house, she takes some pills, leaves Richard with Mrs. Latch and drives to an advanced and quiet hotel. She plans to read a while and kills herself later. This action must be considered crazy by others who all live in the male-dominated society. As the second sex, females are told to be child-bearers in the patriarchy. She lives in such stressful world and wants to flee away-commit a suicide. But, she gives up because suicide is sinful. Then she goes back to home and picks up Richard. After her second child be born, she left her two children and her husband to Canada where she lives guiltily for her life.

She finds a job in Canada to be a librarian to achieve her economical and ideological independence. In the male-dominated society, women's secondary position nearly all determined by the economic condition. In order to live, women have to please men by behaving follows the patriarchal standards and values. The only way to get rid of control of men is to get independent in fiancé. Laura unwilling and fails to be a good housewife. Affected by the spirits and feminist consciousness of Mrs. Dalloway created by Virginia, Laura desperately wants to change her life as an incompetent wife and mother. She'd rather be criticized by others for abandoning her children and husband than put up with a role as a subject and the other in the male-dominated family. she follows her heart to do what she likes and lives independent life all alone. All in all, her struggle and compromise with her role of the other renders her suffers a painful life for she never jumps out of the control of the patriarchy.

\subsection{Clarissa's Relief from Imprisonment}

The following paragraphs will be focused on analyzing Clarissa's relief from the imprisonment. Clarissa, also called Mrs. Dalloway by her ex-lover, is a successful editor who lives in New York in the end of 20th century with her girlfriend Sally. She is an independent woman from economic, politic and emotion unlike Virginia and Laura who are totally rely on their husbands. With the rapid development of science and technology, there are many changes in various social areas, mainly on the economic, politic, ideology and so on in the 20th century. In her age, although many works on people's mind had been done, so as to the feminism, females are still dominated by male members in the society and lesbian also cannot be accepted by majorities. As a highly educated female, Clarissa is acutely aware of the inadequate status females are and wisely notices the suffocated daily life females have to deal with. As the other and the second sex in the patriarchy society, she struggles to fight against the patriarchy by being a lesbian and acting as a protector of her ex-lover.

First, chose to be a lesbian. When Clarissa is young, she falls in love with Richard, a great poet who infects Aids. Unfortunately, Richard is also a gay who chooses Louis - "Louis the farm-boy fantasy, the living embodiment of lazy-eyed carnality" (Michael Cunningham, 1999: 11) finally. Although her heart is aching, she clearly knows that she is not suitable to be a wife to a man.

Second, to be a single mother. Clarissa raises her daughter Julia by her own alone without knowing who her father is for "the father no more than a numbered vial" (Michael Cunningham, 1999: 157). We can imagine that how many obstacles and difficulties she has gone through and brings her daughter up to be a nineteen girl. Julia is a girl who is healthy, energetic and active that others all envy a lot. Being a single mother especially for lesbians, they have to deal with triple and even more kinds of pressure-society, children, themselves and so on.

Third, act as a protector of Richard. Clarissa is an editor who has her own career, social circles and stable income. She has successfully realized her equality with men at least in financial terms. Moreover, she also acts as a protector of Richard who is the representative of patriarchy society. 
In summary, Clarissa takes many measures to fight against the patriarchy and liberates from the imprisonment. However, due to the deep-seated patriarchy and halfway feminine awakening consciousness, Clarissa's fighting is also unthoroughness. As Richard once claimed " that under her pirate-girl veneer lay all the makings of a good suburban life" (Michael Cunningham, 1999: 16). She fears of disdain and discrimination from others for being a lesbian and suffers great sorrows of her daughter's despisement of being a single mother. She cares much about other's view on her and she is just an old-styled lesbian and seems very silly and pathetic. Even Richard totally relies on her, she still needs him to fulfill her value of her life. she completely lost herself, has no way to get rid of it and goes with the stream. For Richard argues that "Clarissa's decision to live with Sally represents, if not some workaday manifestation of deep corruption, at least a weakness on her part that indicts women in general" (Michael Cunningham, 1999: 19). In a word, her halfway of fighting against patriarchy makes her totally lost in her life..

\section{Conclusion}

The hours has achieved a great success in both the book itself and the film adaption. It has been studied on various literary criticisms by numerous specialists and scholars since the publication in 1999. This paper mainly focuses on the key term in feminist literary criticism: patriarchy, to interpret the three lost females revolting against the patriarchy and pursuing their true liberations. In the male-dominated society, women as the other and the second sex have to suffer their fates of being dominated by men, being a housewife and treated indifference in every sectors of society . Virginia, Laura and Clarissa these three tragic women all suffered from the male-dominated society for they all imprisoned by the male-dominators and live too insignificant to lose themselves.

Through the detailed interpretation of their lost images, we can conclude that even they strive to fight for their happiness, independence and freedom, but they will never succeed for their feminist consciousness is not destructive and thorough under that patriarchy society. Although they haven't change their situations and their role of being the other completely and successfully, the courage and efforts they have made to fight against the patriarchy, fight for their liberation could never be forgotten, which inspire the followers to keep struggling. We can learn the lesson of their failure, look ahead and continue to accomplish our goal of female's liberation.

\section{References}

[1] Bell, Quentin. Virginia wolf Biography. London: Hogarth Press,1972.

[2] Cunningham, Michael. The Hours. London: Harper perennial,2006.

[3] De Beauvoir, Simone. The Second Sex. [M] New York: Alfred A. Knopt, 1986.

[4] Eisenstein, Zillah. The Radical Future of Liberal Feminism. [M] New York: Longman, 1981.

[5] Kant, I. 1785, Groundwork of the Metaphysic of Morals, translated and analyzed by H.J. Paton, New York: Harper \& Row, 1948.

[6] Milet, Kate. Sexual Politics. [M] Garden City: Doubleday, 1970.

[7] Tuttle, Lisa. Encyclopedia of Feminism. [M] Harlow: Longman, 1986.

[8] Julia Kristeva. Word, Dialogue and Novel [M].Oxford: Blackwell Publisher Ltd, 1986.

[9] Pyyhtinen,Olli.Simmel and "the social".NewYork:Palgrave Macmillan,2010. 